\title{
Mediastinum Part
}

National Cancer Institute

\section{Source}

National Cancer Institute. Mediastinum Part. NCI Thesaurus. Code C34029.

Any component of the group of organs surrounded by loose connective tissue, separating the two pleural sacs, between the sternum anteriorly and the vertebral column posteriorly as well as from the thoracic inlet superiorly to the diaphragm inferiorly. 